\title{
Infection, course of disease and effects of Canningia tomici in Tomicus piniperda and Tomicus minor (Coleoptera: Curculionidae)
}

\author{
DÖRTE GOERTZ1 \\ MILAN PERNEK ${ }^{2}$ \\ UWE HAENDEL ${ }^{1}$ \\ BERNHARD KOHLMAYR ${ }^{3}$ \\ RUDOLF WEGENSTEINER ${ }^{1}$ \\ University of Natural Resources and Applied \\ Life Sciences, BOKU Vienna, Department of Forest \\ and Soil Sciences, Gregor-Mendel-Straße 33, \\ A-1180 Vienna, Austria. \\ ${ }^{2}$ Croatian Forest Research Institute \\ Cvjetno naselje 41, 41250 Jastrebarsko, Croatia. \\ ${ }^{3}$ Leopoldine-Schlinger-Gasse 4/10, \\ A-1020 Vienna, Austria.

\section{Correspondence:} \\ Milan Pernek \\ E-mail: milan.pernek@sumins.hr
}

Key words: pine shoot beetles, Microsporidia, transmission, survival, Scolytinae

Received February 14, 2017. Revised November 27, 2017. Accepted December 27, 2017.

\begin{abstract}
Background and purpose. The pine shoot beetles Tomicus piniperda and Tomicus minor are secondary tree pests attacking weakened Pinus sylvestris and Pinus nigra. Outbreaks occasionally occur, causing considerable economic damage. The microsporidian pathogen Canningia tomici infects T. piniperda as its principal host. Bioassays were used to study the infectivity, vertical transmission, and effects on survival and fecundity of $\mathrm{C}$. tomici on the two beetle species.
\end{abstract}

Materials and methods. Field collected beetles from several locations in Austria (Lower Austria, Burgenland and Styria), Finland (Hyytiälä), Poland (Sęocin), the Czech Republic (Stará Boleslav), and Croatia (Korenica) (3410 T. piniperda, $413 \mathrm{~T}$. minor) were dissected and evaluated for the presence of C. tomici. Uninfected beetles to be used for infection experiments were only collected from the Austrian sites. Canningia tomici spores were extracted from the infected organs of $\mathrm{T}$. piniperda by dissection and tissues were homogenized in a glass tissue grinder. Microsporidian spores were suspended in water and were counted in a hemocytometer. Infection experiments began with $\mathrm{T}$. piniperda and $\mathrm{T}$. minor as soon as parental beetles were available in the field in spring, or filial beetles emerged from infested log sections in the laboratory. To test the effect of maturation feeding on infection success, filial beetles of both species were either inoculated immediately after emergence from a log section, or were allowed to feed on P. sylvestris twigs for several days before inoculation. Filial beetles were held in Petri dishes containing P. sylvestris twigs at $8^{\circ} \mathrm{C}$ and long-day conditions $(16 \mathrm{~L}: 8 \mathrm{D})$ during the maturation feeding period. Afterwards, they were removed from the twigs, starved for 24 hours, and then inoculated with a 1- $\mu$ l spore suspension or water. All beetles were checked daily until death, dissected and inspected for the presence of $\mathrm{C}$. tomici spores. All data were analyzed with the software program R. Frequency data sets were compared using Chi-square analysis. Multiple comparisons were controlled for Type I errors using the Bonferroni method. The datasets of multiple dependent scale variables were analysed using the $L M$ multivariate procedure, testing the effects of the following factors: year, temperature, inoculation, successful infection, maturation feeding, and sex.

Results. The overall prevalence of C. tomici in T. piniperda was 1.9\%, with significantly more female $\mathrm{T}$. piniperda infected. No infections were observed in T. minor. After feeding spore suspensions to parental and filial T. piniperda and T. minor, between $0 \%$ and $67 \%$ of the beetles were successfully infected, regardless of the incubation temperature or sex of the beetles. Survival time was significantly influenced by the incubation temperature and successful infection; in filial beetles the maturation feeding 
period was also an important factor. A lower incubation temperature and successful infection resulted in longer survival of individuals of both species.

Conclusion. We conclude that when $\mathrm{C}$. tomici infects the reproductive organs of its hosts, the lifespan of the host is extended, leading to increased reproduction, transmission, and survival of the pathogen in host populations.

\section{INTRODUCTION}

In northern and central Europe, the pine shoot beetles Tomicus piniperda (L.) and Tomicus minor (Hartig) are tree pests that attack weakened Pinus sylvestris (L.) and Pinus nigra (Arnold) as their principal host species $(1,2)$. T. piniperda occurs throughout Europe, from the northernmost regions of Norway, Finland, and Sweden, to the south of Central Europe. It has spread to China (3) and was accidentally introduced into the USA (4) and Canada (5, 6). The related species T. minor occurs sympatrically with $T$. piniperda, but uses different stem regions on pine trees. It is widespread throughout Europe, from Scandinavia to the Mediterranean region (2). Depending on the ambient temperature, overwintering adults of both species initiate flight activity in spring, with $T$. minor flying later than T. piniperda. Following mating, females tunnel mother galleries into the phloem and lay one clutch of eggs. Re-emergence of adult beetles occurs when breeding and oviposition is completed. Subsequently, they bore into shoots of mature pine trees for regeneration feeding, followed by the initiation of a sister brood in uninfested regions of the same tree or in uninfested logs. Both species may infest the same host tree; T. piniperda prefers the lower parts of trees with thick bark for breeding sites, while T. minor prefers trunk with thin bark. Both species bore/tunnel into one-year-old pine shoots for maturation feeding $(7,8)$. Shoot feeding by young callow adults and older adult beetles causes the primary injuries to pine trees, resulting in twig death and weakening of the infested trees $(9,10)$. However, both beetle species are known as secondary pests in pine stands during the endemic phase. Nonetheless outbreaks occur occasionally, during which the beetles are able to attack vigorous trees (11). This causes considerable economic damage, particularly by $T$. minor. In addition to infesting living trees, both beetle species infest wind thrown, felled, and firedamaged trees, as well as fresh logs (7, 12-14). Moreover, these phloeophagous beetles introduce blue stain fungi (e.g. Leptographium wingfieldii, Ophiostoma minus), which interfere with water conduction, accelerate tree death, (1517) and reduce the commercial value of timber when it develops blue stain.

Biological control has never been seriously attempted with bark beetles $(18,19)$ and should be reconsidered in light of the results of a study conducted by Kohlmayr et al. (20), which reports the presence of the microsporidium Canningia tomici in cells of the midgut epithelium, adi- pose tissue, and ovariols of $T$. piniperda. Little has been reported about the pathogen-host interaction, effects of infection in T. piniperda, or the epidemiological consequences in populations. Additionally, because T. piniperda and T. minor can occur coincidentally in pine logs, transmission of pathogens from one species to the other one is theoretically possible.

The aim of this study was to investigate the effects of the microsporidium C. tomici on its host, T. piniperda, and on the congeneric species $T$. minor. Our research focused on the infectivity of $C$. tomici to both beetle species, as well as the effects of infection on the survival time of T. piniperda and T. minor parental and offspring beetles. We considered factors such as temperature and the influence of $C$. tomici infection on the fecundity of adult beetles and tested for vertical transmission of $C$. tomici.

\section{MATERIAL AND METHODS}

\section{Host insects and pathogens}

Adult beetles were collected in spring when T. piniperda (March to April) and T. minor (April to May) initiated swarming. Sampling was conducted over the entire 3-year period (2002-2004) at sampling sites with known populations of healthy, uninfected parental and filial beetles, and sites where $C$. tomici-infected beetles were known to occur and fresh spores could be obtained for experiments (20). T. piniperda and T. minor were collected from several locations in Austria (Lower Austria, Burgenland and Styria), Finland (Hyytiälä), Poland (Sękocin), the Czech Republic (Stará Boleslav), and Croatia (Korenica). Uninfected beetles for infection experiments were only collected from the Austrian sites; infected $T$. piniperda were only found in samples from Finland, Poland, and the Czech Republic.

Parental beetles of both species were collected in the field by hand (either cut out of the bark from trap trees or beetle-infested log sections) and brought to the laboratory. These beetles were stored in a refrigerator $\left(\right.$ at $4^{\circ} \mathrm{C}$ ) until inspection or in an incubator at $8^{\circ} \mathrm{C}$ and long-day rearing conditions (16L:8D) until they were to be used in experiments. Beetle-infested log sections were incubated in the insectary at the University of Natural Resources and Life Sciences (BOKU) in breeding cages at $21^{\circ} \mathrm{C}$ $\left( \pm 1.5^{\circ} \mathrm{C}\right)$ and at long-day conditions $(16 \mathrm{~L}: 8 \mathrm{D})$. Emerging parental beetles and later filial beetles (recognized by their light brown color) were removed from breeding cages daily. A subsample thereof ( $\mathrm{n} \geq 50$; tables 2 and 3) was dissected to ensure that they were uninfected and could be used for infection experiments.

Canningia tomici spores were extracted from the infected organs of T. piniperda by dissection and homogenization of tissues (midgut epithelium, the gut muscules, Malpighian tubules, connective tissues, adipose tissues 
Table 1. Canningia tomici infection in field collected Tomicus piniperda.

\begin{tabular}{|c|c|c|c|c|c|c|c|}
\hline Year & Country & $\hat{0}$ & q & Total & $\hat{O}_{\mathrm{inf}}$ & $q_{\mathrm{inf}}$ & Total inf \\
\hline \multirow[t]{4}{*}{2002} & Austria & 216 & 222 & 438 & 0 & 0 & 0 \\
\hline & Czech Republic & 100 & 125 & 225 & 0 & 1 & 1 \\
\hline & Finland & 62 & 137 & 199 & 4 & 14 & 18 \\
\hline & Poland & 75 & 77 & 152 & 0 & 2 & 2 \\
\hline \multirow[t]{5}{*}{2003} & Austria & 197 & 251 & 448 & 0 & 0 & 0 \\
\hline & Czech Republic & 142 & 156 & 298 & 0 & 0 & 0 \\
\hline & Finland & 26 & 190 & 216 & 1 & 24 & 25 \\
\hline & Poland & 128 & 220 & 348 & 3 & 2 & 5 \\
\hline & Croatia & 56 & 46 & 102 & 0 & 0 & 0 \\
\hline \multirow[t]{6}{*}{2004} & Austria & 119 & 140 & 259 & 1 & 0 & 1 \\
\hline & Czech Republic & 152 & 191 & 343 & 1 & 1 & 2 \\
\hline & Finland & 28 & 62 & 90 & 5 & 3 & 8 \\
\hline & Poland & 94 & 127 & 221 & 2 & 1 & 3 \\
\hline & Croatia & 26 & 45 & 71 & 0 & 1 & 1 \\
\hline & Total & 1421 & 1989 & 3410 & 17 & 49 & 66 \\
\hline
\end{tabular}

and the gonads) in distilled water, then purified by density gradient centrifugation (21). The spores were suspended in water and counted in a Neubauer improved hemocytometer.

\section{Inoculation of host insects and pathogen diagnosis}

Inoculation of parental and filial $T$. piniperda and $T$. minor was conducted after the beetles had undergone a 24-hour starvation period by force feeding a 1- $\mu$ l C. tomici spore suspension using a standard vaccinating eyelet. The spore concentration fed to the beetles ranged between 30 spores $/ \mu$ land $1.28 \times 10^{4}$ spores $/ \mu 1$, depending on the intensity of infection in the collected beetles (Table 1). The beetles in the control group were fed $1 \mu \mathrm{l}$ water instead of the spore suspension. Beetles that fed on the spore suspension within two minutes were transferred into Petri dishes containing bark chips. The bark chips were changed every other day. The number of beetles per Petri dish varied from 1 to 50 , depending on the number of beetles currently available. Following inoculation, and unless otherwise indicated, all beetles were stored under long-day conditions in incubators, either at $16^{\circ} \mathrm{C}\left( \pm 1^{\circ} \mathrm{C}\right)$ or $21^{\circ} \mathrm{C}\left( \pm 1^{\circ} \mathrm{C}\right)$, until death. Inoculated beetles were stored separately from control beetles. Both beetle species and parental and filial beetles were tested separately.

At the termination of each experiment, inoculated and control beetles were examined for the presence of $C$. tomici spores. Tissues were excised with fine scissors and fresh smears on microscope slides were inspected under bright field and phase contrast microscopy at 400x and 1000x magnification (22).

\section{Effects of Canningia tomici on the survival time of parental and filial Tomicus piniperda and parental and filial Tomicus minor}

Infection experiments began with $T$. piniperda and $T$. minor as soon as parental beetles were available in the field in spring, or filial beetles emerged from infested log sections in the laboratory. Depending on the number of beetles that were collected or had emerged, varying numbers of parental or filial T. piniperda or $T$. minor were inoculated (Table 4 and 7 ).

To test the effect of maturation feeding on infection success, filial beetles of both species were either inocu-

Table 2. Canningia tomici infection in field collected Tomicus minor.

\begin{tabular}{|lccccccc|}
\hline Year & Country & $\hat{0}$ & $\phi$ & Total & $\hat{0}_{\text {inf }}$ & $q_{\text {inf }}$ & Total inf \\
\hline 2002 & Austria & 135 & 157 & 292 & 0 & 0 & 0 \\
& Czech Republic & 6 & 8 & 14 & 0 & 0 & 0 \\
2003 & Austria & 26 & 28 & 54 & 0 & 0 & 0 \\
2004 & Austria & 14 & 39 & 53 & 0 & 0 & 0 \\
& Total & 181 & 232 & 413 & 0 & 0 & 0 \\
\hline
\end{tabular}


Table 3. Canningia tomici infection in Tomicus minor parental beetles. Number and percentages of inoculated and successfully infected beetles and the number of control beetles, reared either at $16^{\circ} \mathrm{C}$ or at $21^{\circ} \mathrm{C}$, are displayed below.

\begin{tabular}{|lcccccc|}
\hline Temperature & \multicolumn{3}{c}{$16^{\circ} \mathrm{C}$} & & \multicolumn{2}{c|}{$21^{\circ} \mathrm{C}$} \\
\hline Sex & Female & Males & unknown & Female & Male & unknown \\
$\mathrm{N}_{\text {inoculated }}$ & 111 & 41 & 6 & 110 & 66 & 30 \\
$\mathrm{~N}_{\text {infected }}$ & 55 & 20 & 46 & 32.73 & 25.76 & 9 \\
$\%$ infected & 49.55 & 48.78 & 66.67 & 61 & 50 & 13 \\
$\mathrm{C}$ & 41 & 16 & 4 & 0 & 0 & 0 \\
$\mathrm{C}_{\text {infected }}$ & 1 & 0 & 0 & 0 & 0 \\
\hline
\end{tabular}

Table 4. Factors explaining the mean survival time of male and female Tomicus minor parental beetles. A linear model of survival time was calculated (ANOVA, $F=15.46, r^{2}=0.2839, d f=6$ o 549, $p<2.2 * 10-16)$. Asterisks show the significance level: $p<0.05$ *, $p<0.01^{* *}, p<0.001^{* * *}$

\begin{tabular}{|lcccc|}
\hline Factor & Mean Sq & $\mathrm{F}$ & $\mathrm{p}$ & \\
\hline Year & 5377 & 9.787 & 0.0019 & $* *$ \\
Temperature & 77051 & 140.241 & $<2.2^{*} 10-16$ & $* * *$ \\
$\begin{array}{l}\text { Inoculation } \\
\begin{array}{l}\text { Successful } \\
\text { infection }\end{array}\end{array}$ & 144 & 0.262 & 0.6092 & \\
$\begin{array}{l}\text { Sex } \\
\text { Isolate / Number } \\
\text { of spores }\end{array}$ & 23219 & 42.260 & $1.842^{*} 10-8$ & $* * *$ \\
\hline
\end{tabular}

lated immediately after emergence from a log section, or were allowed to feed on P. sylvestris twigs for several days prior to inoculation. Filial beetles were held in Petri dish- es containing $P$. sylvestris twigs at $8^{\circ} \mathrm{C}$ and long-day conditions (16L:8D) during the maturation feeding period. Afterwards, they were removed from the twigs, starved for 24 hours, and then inoculated with a $1-\mu 1$ spore suspension or water. All beetles (infected or in the control group) were held in Petri dishes as described above and checked daily until death. Afterwards, they were dissected and inspected for the presence of $C$. tomici spores.

\section{Vertical transmission of Canningia tomici and its effects on the fecundity of Tomicus piniperda and Tomicus minor}

In order to examine the consequences of a $C$. tomici infection on the fecundity of $T$. piniperda and T. minor, parental females and male beetles were inoculated with a $1-\mu l$ spore suspension, using the same mode of inoculation as described above. Individual pairs of $T$. piniperda or $T$. minor were placed onto fresh log sections of $P$. sylvestris respectively and caged using capsule pits (23). Caging breeding pairs on fresh log sections forced them to initiate their galleries at a selected point in the bark. This proce-

Table 5. Survival time (mean $\pm S D$ ) of Tomicus minor parental beetles in the control group, of beetles successfully infected with Canningia tomici and of beetles inoculated but not successfully infected with C. tomici. All beetles were incubated either at $16^{\circ} \mathrm{C}$ or at $21^{\circ} \mathrm{C}$.

\begin{tabular}{|ccccc|}
\hline Temperature & Sex & Control & Sucessfully infected & Inoculated \\
\hline $16^{\circ} \mathrm{C}$ & 0 & $41.8 \pm 38.7$ & $54.6 \pm 21.8$ & $62.0 \pm 42.9$ \\
$21^{\circ} \mathrm{C}$ & 0 & $23.8 \pm 19.9$ & $30.4 \pm 10.5$ & $15.4 \pm 11.8$ \\
$16^{\circ} \mathrm{C}$ & + & $49.7 \pm 41.1$ & $49.2 \pm 15.8$ & $30.0 \pm 34.7$ \\
$21^{\circ} \mathrm{C}$ & + & $27.6 \pm 18.2$ & $32.9 \pm 12.4$ & $10.6 \pm 10.2$ \\
\hline
\end{tabular}

Table 6. Canningia tomici infection in Tomicus minor filial beetles. The number and percentages of inoculated and successfully infected beetles and the number of control beetles, reared either at $16^{\circ} \mathrm{C}$ or at $21^{\circ} \mathrm{C}$, are displayed below.

\begin{tabular}{|lcccccccccc|}
\hline Temperature & \multicolumn{9}{c}{$16^{\circ} \mathrm{C}$} & \multicolumn{3}{c|}{$21^{\circ} \mathrm{C}$} \\
\hline Sex & \multicolumn{2}{c}{ Female } & \multicolumn{2}{c}{ Males } & unknown & Female & & Male & unknown \\
\hline mat. feeding & Yes & No & Yes & No & - & Yes & No & Yes & No & - \\
$\mathrm{N}_{\text {inoculated }}$ & 63 & 16 & 37 & 18 & 43 & 77 & 2 & 35 & 3 & 57 \\
$\mathrm{~N}_{\text {infected }}$ & 22 & 3 & 11 & 2 & 16 & 11 & 0 & 10 & 0 & 8 \\
$\%$ infected & 34.92 & 18.75 & 29.73 & 11.11 & 37.21 & 13.58 & 0.00 & 8.57 & 0.00 & 14.03 \\
$\mathrm{C}$ & 25 & & 18 & & 7 & 27 & & 20 & 15 \\
$\mathrm{C}_{\text {infected }}$ & 0 & & 0 & & 0 & 0 & & 0 & 0 \\
\hline
\end{tabular}


Table 7. Factors explaining the mean survival time of male and female T. minor filial beetles. A linear model of survival time was calculated ( ANOVA, $\left.F=12.61, r^{2}=0.345, d f=20 \& 439, p<2.2^{*} 10-16\right)$. Asterisks show the significance level: $p<0.05^{*}, p<0.01^{* *}, p<0.001{ }^{* * *}$

\begin{tabular}{|c|c|c|c|c|}
\hline Factor & Mean Sq & $\mathrm{F}$ & $\mathrm{p}$ & \\
\hline Year & 687 & 3.252 & 0.072 & \\
\hline Temperature & 11970 & 56.662 & $2.964^{*} 10-13$ & $* * *$ \\
\hline Isolate/Number of spores & 24995 & 7.888 & $8.318^{*} 10-16$ & $* * *$ \\
\hline Maturation feeding & 1799 & 8.515 & 0.0037 & ** \\
\hline Successful infection & 13393 & 63.398 & $1.460 * 10-14$ & $* * *$ \\
\hline Sex & 443 & 2.097 & 0.1483 & \\
\hline
\end{tabular}

Table 8. Survival time (mean $\pm S D$ ) of Tomicus minor filial beetles of the control group, of beetles successfully infected with Canningia tomici and of beetles inoculated but not successfully infected with C. tomici. All beetles were incubated either at $16^{\circ} \mathrm{C}$ or at $21^{\circ} \mathrm{C}$.

\begin{tabular}{|ccccc|}
\hline Temperature & Sex & Control & Sucessfully infected & Inoculated \\
\hline $16^{\circ} \mathrm{C}$ & 0 & $17.8 \pm 2.9$ & $31.8 \pm 10.2$ & $21.2 \pm 18.6$ \\
$21^{\circ} \mathrm{C}$ & 0 & $5.3 \pm 4.6$ & $28.0 \pm 12.6$ & $10.3 \pm 12.5$ \\
$16^{\circ} \mathrm{C}$ & + & $23.4 \pm 22.7$ & $31.3 \pm 10.7$ & $25.1 \pm 24.4$ \\
$21^{\circ} \mathrm{C}$ & + & $14.9 \pm 11.1$ & $28.1 \pm 11.3$ & $15.6 \pm 15.1$ \\
\hline
\end{tabular}

dure made it possible to follow the galleries of infected parental beetles and their offspring. In order to prevent dehydration of the Pinus log sections, logs were sprayed with tap water once a week. Log sections were incubated in the laboratory at $21^{\circ} \mathrm{C}\left( \pm 1.5^{\circ} \mathrm{C}\right)$ and galleries were opened after 7-8 weeks. Parental beetles were recollected from the capsule pits after death or re-emergence and examined for microsporidian infection. All eggs, larvae, pupae, and callow adults were removed, counted, dissected, and inspected under bright field and phase contrast microscopy.

\section{Analysis of data}

All data were analyzed with the software program $\mathrm{R}$ (24). Frequency data sets were compared using Chi-square analysis. Multiple comparisons were controlled for Type I errors using the Bonferroni method. The datasets of multiple dependent scale variables were analysed using the LM multivariate procedure, testing the effects of the following factors: year, temperature, inoculation, successful infection, maturation feeding, and sex.

\section{RESULTS}

\section{Prevalence of Canningia tomici in Tomicus piniperda and Tomicus minor}

Different numbers of female (45 to 251) and male (26 to 216) T. piniperda were collected from field sites in four (2002) or five (2003 and 2004) countries. In total, 3410 beetles were collected and dissected (Table 1). A total of 66 T. piniperda were found to be infected with C. tomi- ci. Significantly more females $(2.5 \%)$ were infected with C. tomici than males (1.2\%) (Chi-square test, $\chi^{2}=97.6$, $\left.\mathrm{df}=1, \mathrm{p}<2.2^{*} 10^{-6}\right)$. Additionally, a significantly higher proportion of $T$. piniperda from sites in Finland and Poland were infected with $C$. tomici (Chi-square test, $\left.\chi^{2}=212.3, \mathrm{df}=4, \mathrm{p}<2.2^{*} 10^{-6}\right)$, as compared to the other countries.

A total of 413 T. minor beetles were field-collected from two countries (2002: Austria and Czech Republic) and one country (Austria: 2003 and 2004) (Table 2). None of the T. minor individuals were found to be infected with $C$. tomici. The percentage of female beetles was $56.2 \%$. During the second and third year of the study period, fewer beetles were dissected and checked for a $C$. tomici infection.

\section{Infectivity and effects of Canningia tomici on Tomicus piniperda}

\section{Parental generation}

Inoculation of $132 T$. piniperda parental beetles (67 females, 54 males and 11 beetles of unknown sex) and incubation at $16^{\circ} \mathrm{C}$ induced a $C$. tomici infection in one female $(0.76 \%)$ that survived 113 days post-inoculation (dpi). None of the male beetles were successfully infected with $C$. tomici. When $165 T$. piniperda parental beetles (75 females, 73 males and 17 beetles of unknown sex) were inoculated with $C$. tomici and incubated at $21{ }^{\circ} \mathrm{C}$, slightly more beetles $(3.03 \%, n=5)$ were successfully infected, as compared to beetles incubated at $16^{\circ} \mathrm{C}(n=1)$. One infected female and four infected males died $10 \mathrm{dpi}$ and $15 \mathrm{dpi}$, respectively. 
None of the control beetles $\left(16{ }^{\circ} \mathrm{C}: 39\right.$ females, 36 males and 7 beetles of unknown sex; $21^{\circ} \mathrm{C}$ : 48 females, 40 males and 4 beetles of unknown sex) were infected with $C$. tomici.

\section{T. piniperda filial generation}

Compared to the parental generation, a higher proportion $(10.82 \%)$ of inoculated T. piniperda filial beetles incubated at $16^{\circ} \mathrm{C}$ were successfully infected with $C$. tomici. There were 194 beetles in total ( 58 females with maturation feeding and 22 females without; 57 males with maturation feeding and 17 males without; 11 beetles of unknown sex with maturation feeding and 40 beetles without). Seven females (five with maturation feeding and two without) and eight males (six with maturation feeding and two without) were successfully infected with $C$. tomici. Of 307 inoculated T. piniperda filial beetles (68 females with maturation feeding and 43 without; 66 males with maturation feeding and 43 without; 83 beetles of unknown sex) incubated at $21^{\circ} \mathrm{C}, 6.19 \%$ were successfully infected with $C$. tomici. Five females and five males with maturation feeding were successfully infected. No female and three males without maturation feeding were infected. Neither the sex nor the incubation temperature significantly influenced the proportion of successfully infected beetles; however, a slightly higher percentage of males were infected with $C$. tomici than females (Chisquare test, $\tau=4, \mathrm{df}=1, \alpha>0.05 ; 16^{\circ} \mathrm{C}: \chi^{2}=0.5,21^{\circ} \mathrm{C}$ : $\chi^{2}=0.7$, female: $\chi^{2}=0.1$, male: $\chi^{2}=0.3$ ).

None of the control beetles ( $16^{\circ} \mathrm{C}: 53$ females, 57 males and 18 beetles of unknown sex, $21^{\circ} \mathrm{C}$ : 72 females, 77 males and 54 beetles of unknown sex) were infected with $C$. tomici.

\section{Infectivity and effects of Canningia tomici on Tomicus minor}

\section{Parental generation}

Incubating of 158 inoculated T. minor parental beetles at $16{ }^{\circ} \mathrm{C}$, resulted in almost $50 \%$ infection with $C$. tomici (Table 3). Of 206 inoculated T. minor incubated at $21^{\circ} \mathrm{C}$, $30.1 \%$ became infected. Neither sex nor the incubation temperature influenced the proportion of $T$. minor parental beetles successfully infected with $C$. tomici (Chi-square test, $\tau=4, \mathrm{df}=1, \alpha>0.05,16^{\circ} \mathrm{C}: \chi^{2}=0.01 ; 21^{\circ} \mathrm{C}: \chi^{2}=$ 0.952; female: $\chi^{2}=6.4$; male: $\chi^{2}=5.9$, Table 4 ).

The mean survival time of filial $T$. minor beetles was significantly influenced by the incubation temperature (ANOVA, $\mathrm{p}<2.2^{*} 10^{-16}$, table 5), the isolate and/or spore concentration used (ANOVA, $\mathrm{p}=4.13^{*} 10-5$ ), and the successful establishment of $C$. tomici in T. minor (ANOVA, $\left.\mathrm{p}=1.842^{*} 10-8\right)$. Mean survival time was not influenced by sex of the beetles. Beetles incubated at $16^{\circ} \mathrm{C}$ lived 18-47 days longer than beetles incubated at $21^{\circ} \mathrm{C}$ (Table
5). Infected parental T. minor beetles lived up to 12 days longer than beetles in the control group.

One female in the control group incubated at $16^{\circ} \mathrm{C}$ was infected with $C$. tomici.

\section{T. minor filial generation}

When 177 T. minor filial beetles were incubated at $16^{\circ} \mathrm{C}$ and 174 inoculated at $21^{\circ} \mathrm{C}, 30.51 \%$ and $16.67 \%$, respectively, were successfully infected with $C$. tomici (Table 6). A lower but not significant proportion of males were successfully infected with $C$. tomici compared to females (Chi-square test, $\tau=4, \mathrm{df}=1, \alpha>0.05,16^{\circ} \mathrm{C}: \chi^{2}=$ 1.024, $21^{\circ} \mathrm{C}: \chi^{2}=2.8$, female: $\chi^{2}=8.2$, male: $\chi^{2}=0.01$ ). Furthermore, we did not observe any effect of the incubation temperature on the proportion of beetles successfully infected with $C$. tomici.

The mean survival time of filial T. minor beetles was significantly influenced by the incubation temperature (ANOVA, $p=2.964^{*} 10-13$, Table 7 ), the duration of the maturation feeding $(\mathrm{p}=0.0037)$, successful infection with $C$. tomici (ANOVA, $\mathrm{p}=1.460^{*} 10-14$ ), the isolate and/or spore concentration used (ANOVA, $\mathrm{p}=8.318^{*} 10$ 16) . Mean survival time of beetles was not influenced by sex and the sucessful inoculation with $C$. tomici spores. Beetles incubated at $16^{\circ} \mathrm{C}$ lived 3-13 days longer than beetles incubated at $21^{\circ} \mathrm{C}$ (Table 8). Beetles successfully infected with $C$. tomici lived up to 23 days longer than beetles in the control group.

\section{Vertical transmission of Canningia tomici}

\section{Tomicus piniperda}

In total, 35 pairs of $T$. piniperda parental beetles were inoculated with a spore suspension of $C$. tomici and 15 pairs were inoculated with water. None of beetles inoculated with the spore suspension were infected with $C$. tomici.

\section{Tomicus minor}

In total, 60 pairs of T. minor parental beetles were inoculated with a spore suspension of $C$. tomici and 37 pairs were inoculated with water. Inoculation with $C$. tomici was successful in $20 \mathrm{~T}$. minor pairs. None of the control beetles were infected with $C$. tomici. No infection was found in progeny of the infected parental $T$. minor. Comparing the breeding systems of pairs inoculated with C. tomici with systems of the control group, no significant differences were found in the total length of the mother galleries (Wilcoxon rank sum test, $\mathrm{W}=324, \mathrm{p}=0.6412$ ), the total number of progeny produced (Wilcoxon rank sum test, $\mathrm{W}=328, \mathrm{p}=0.5809)$, nor the progeny $/ \mathrm{cm}$ mother gallery (Wilcoxon rank sum test, $\mathrm{W}=238, \mathrm{p}=$ $0.2169)$. The total length of the mother gallery produced by infected pairs was $7.0 \pm 4.0 \mathrm{~cm}$, with a length of $2.4 \pm$ $3.2 \mathrm{~cm}$ for the left arm and $4.7 \pm 4.3 \mathrm{~cm}$ for the right arm. The total length of the mother gallery produced by beetle 
pairs in the control group was $9.0 \pm 8.2 \mathrm{~cm}$; the length of the left arm was $4.3 \pm 6.5 \mathrm{~cm}$ and the length of the right arm was $4.7 \pm 6.3 \mathrm{~cm}$. On average, an infected female laid $27.4 \pm 18.4$ in each mother gallery; a female in the control group produced an average of $32.2 \pm 31.5$ in each mother gallery.

\section{DISCUSSION}

Pine shoot beetles are reported to be a serious problem in Scandinavian forestry, since they damage infested pine trees by feeding in pine shoots, causing growth loss and crown damage; by introducing bluestain fungi, degrading timber quality; and by killing weakened trees (25). Several microsporidian species, a diverse group of obligate intracellular pathogens infecting arthropods and fish (26, 27), belong to the natural enemy complex of bark beetles (19). In some cases, they are believed to have the potential for biological control in other host-pathogen systems (28).

T. piniperda and T. minor are widely distributed species in the Palearctic region (29); their current distribution correlates with the occurrence of its host species of the genus Pinus (30, 31). As a cold-tolerant species (31), T. piniperda prefers mean temperatures of approximately $17^{\circ} \mathrm{C}$ during the summer and $0^{\circ} \mathrm{C}$ during the winter months; it is absent in regions with higher mean temperatures during the warmest or coldest seasons of the year (30). Furthermore, T. piniperda and T. minor are, in contrast to Tomicus destruens, unable to develop in warm and dry climates (32). This clear preference might also be reflected in our data. The mean survival time of both beetle generations, i.e. parental and filial beetles, as well as both sexes, was significantly influenced by incubation temperature. Parental T. minor incubated at $16^{\circ} \mathrm{C}$ lived up to 4 times longer than beetles incubated at $21^{\circ} \mathrm{C}$. The survival time of filial T. minor was prolonged between 3 and 8 days when incubated at the lower temperature. Additionally, this might be supported by the higher prevalence of beetles both infected with $C$. tomici and collected in countries north of Austria.

Another interpretation of these data might conclude that beetles incubated at lower temperatures died later due to their reduced metabolism and the better food quality of the bark chips, which did not decay as quickly.

The mean survival time of Tomicus minor was also influenced by the successful establishment of a $C$. tomici infection. The results of our data indicate that a successful infection of $T$. minor did not negatively influence the mean survival time of the tested beetles; surprisingly, it resulted in a prolonged survival time of the infected $T$. minor. Such behavior reported also from other microsporidia infected insect species e.g. gypsy moth, Lymantria dispar L. (33). To our knowledge, most of the studies on the effects of microsporidia in insects report a reduced survival time and higher mortality rate in infected insects.
Only few studies report no negative effects of a microsporidian parasite on its native host; although the infection of two lady beetles resulted in prolonged larval development and no higher mortality was recorded (34-36). We suggest that the prolonged survival time of infected $T$. minor might increase the possibility of infecting organs other than the gut, such as the ovaries that make vertical transmission of the microsporidian pathogen possible.

The life cycle of T. minor or T. piniperda under the bark of infested trees suggests that vertical transmission might be the main transmission pathway of $C$. tomici. If horizontal transmission does occur, it would be expected to occur during the period of maturation feeding of the beetles and/or the following mating and tunneling of the egg galleries in the breeding chambers. Our results further indicate that the potential for horizontal transmission before maturation feeding period is low; we were never able to infect $100 \%$ of the test beetles and successful infection of filial beetles increased with a maturation feeding period. Though the infection of gonads and the vertical transmission of $C$. tomici has been reported for $T$. piniperda (20), we were not able to provide any further evidence for the vertical transmission of $C$. tomici in both tested beetle species. Our results show that the successful infection of T. piniperda and T. minor offspring did not depend on the rearing temperature or sex of the beetles but was influenced by the duration of maturation feeding. There are probably several reasons for our low success in orally infecting T. piniperda and T. minor. First, we were unable to store $C$. tomici spores in liquid nitrogen, which runs counter to reported storage conditions for several microsporidian species (ref), and C. tomici spores were only viable for few weeks when stored in a refrigerator at $7^{\circ} \mathrm{C}$ (unpublished data). Additionally, the process of inoculation might be suboptimal, as Tomicus spp. feed in the phloem of trees without drinking liquid water, and were force-fed $1 \mu$ of a liquid spore suspension. Additionally, physiological conditions inside the gut may change during the lifecycle of the beetles. Parental beetles and callow adult beetles that had just emerged from the pupal chamber were less susceptible to infection with $C$. tomici than filial beetles with at least two weeks of maturation feeding.

We recorded a higher prevalence of infected $T$. piniperda collected in Finland and Poland. This result may reflect the relatively higher abundance of both Pinus ssp. and these two pine shoot beetle species in these countries (11). Permanent food sources may be conducive to a permanent bark beetle population and further enhance endemism of pathogens in its host population. Also, our results indicate a longer survival time of both beetle species at lower temperatures and the successful infection with $C$. tomici also resulted in a prolonged survival time of both species. We conclude that the lower mean temperatures in more northern habitats may favor the devel- 
opment and successful transmission of $C$. tomici in $T$. piniperda beetles.

One individual T. minor beetle in the control group was infected with $C$. tomici. We do not have a conclusive explanation for this. It is unclear as to whether or not this infection occurred before the beetle was collected in the field, or if the infection was due to contamination or mistakenly assigning the beetle to the control group in the laboratory. We would prefer to exclude the possibility of a natural infection for two reasons: 1) no microsporidian species have been reported to infect $T$. minor and 2) we only used beetles for all our experiments collected at field sites without any record of an infection with $C$. tomici in T. piniperda and T. minor.

C. tomici was originally isolated from T. piniperda but was also found to be infective for T. minor in the laboratory. Infected T. minor were found to be infected to a higher degree than T. piniperda. Malformed spores were not observed. These results indicate that $C$. tomici is also a pathogen for T. minor, although $C$. tomici has not been reported in field-collected $T$. minor beetles, and we were also unable to show that $C$. tomici is vertically transmitted to its progeny. A broader ecological host range of C. tomi$c i$ that includes both $T$. piniperda and $T$. minor would imply that horizontal transmission of $C$. tomici might be difficult to achieve for several reasons. In principle, both species occur in the same habitat and are also observed to infest the same host trees; therefore, at least food-related gut conditions may be nearly identical in both species. Nevertheless, the species exhibit some degree of niche separation, thereby decreasing the potential of horizontal transmission of $C$. tomici between species. T. piniperda usually infests the lower trunk of host trees with thicker bark, and swarms and infests weakened trees earlier. $T$. minor prefers to infest the upper parts of tree trunks with thinner bark, initiates the swarming period later, and infests weakened trees often already colonized by $T$. piniperda. This separation in space and time of the two beetle species limits the opportunity for horizontal transmission of $C$. tomici. Although we were unable to provide evidence of pathogen transfer from parental beetles to offspring, results of an earlier study suggest that $C$. tomici is transmitted vertically in T. piniperda (20).

\section{Acknowledgements}

We present this paper in memory of Prof. Dr. Jaroslav Weiser (Czech Republic).

We thank the Austrian Science Fund (Project: P 14994 - B06), the OEAD Ernst Mach scholarship, Prof. Dr. Kari Heliövaara and Dr. Päivi Lyytikäinen-Saarenmaa (Institute of Applied Zoology, University of Helsinki, Finland), Dr. Jacek Hilszczański (IBL Forest Research Institute, Sękocin Stary, Poland), Dr Miloš Knížek (Forestry and Game Management Research Institute, Jíloviště, Czech Republic), foresters and forest owners in Austria (Ing.
Wolfgang Meissl, Ing. Peter Dorner, Maria and Karl Wosika), and Roman Wanjek and Andrea Stradner from BOKU University.

\section{REFERENCES}

1. BRIGHT DE., SKIDMORE RE 1997 A Catalog of Scolytidae and Platypodidae (Coleoptera), Supplement 1: (1990-1994). NRC Research Press, Ottawa.

2. PFEFFER A 1995 Zentral- und westparäarktische Borken- und Kernkäfer (Coleoptera: Scolytidae, Platypodidae). Pro Entomologica Naturhistorische Museum Basel, Basel.

3. YE H, ZHAO ZM 1995 Life table of Tomicus piniperda (L.) (Col., Scolytidae) and its analysis. J Appl Entomol 119: 145-148. https://doi.org/10.1111/j.1439-0418.1995.tb01261.x

4. HAACK RA 1997 Early history and spread of Tomicus piniperda in North America. In: Japanese Beetle and the pine shoot beetle regulatory review: Proceedings, Louisville, Kentucky, p 26

5. POLAND TM, HAACK RA 2000 Pine shoot beetle, Tomicus piniperda (Col., Scolytidae), responses to common green leaf volatiles. J Appl Ent 124: 63-69.

https://doi.org/10.1046/j.1439-0418.2000.00448.x

6. MORGAN R, DE GROOT P, SMITH SM 2002 Susceptibility of pine plantations to attack by the pine shoot beetle (Tomicus piniperda) in southern Ontario. [Northeastern Forest Pest Council Meeting] (http://www.fcmr.forestry.ca/index-e/what-e/science-e/ entomology-e/nfpc-e/agenda-e.html).

7. LANGSTROM B 1984 Windthrown Scots pines as brood material for Tomicus piniperda and T. minor. Silva Fenn 18: 187-198. https://doi.org/10.14214/sf.a15392

8. ANNILA E, LANGSTROM B, VARAMA M, HIUKKA R, NIEMELA P 1999 Susceptibility of defoliated Scots pine to spontaneous and induced attack by Tomicus piniperda and Tomicus minor. Silva Fenn 33: 93-106. https://doi.org/10.14214/sf.660

9. EIDMANN HH 1992 Impact of bark beetles on forests and forestry in Sweden. J Appl Entomol 114: 193-200. https://doi.org/10.1111/j.1439-0418.1992.tb01114.x

10. MCCULLOGH DG, SMITLEY DR 1995 Evaluation of insecticides to reduce maturation feeding by Tomicus piniperda (Col.: Scolytidae) in Scots pine. J Econ Entomol 88: 693-699. https://doi.org/10.1093/jee/88.3.693

11. GREGOIRE JC, EVANS HF 2004 Damage and control of organisms an Overview. Bark and Wood Boring Insects in Living Trees in Europe, a Synthesis, pp. 19-37. In: Lieutier F, Day K, Battisti A, Grégoire JC, Evans H [eds], Springer, Dordrecht.

12. SCHWERDFEGER F 1968 Käferbefall und Verblauung an sommergefälltem, nicht entrindetem Kiefernholz. Forst- und Holzwirt 23: $1-3$

13. FERNANDEZ MMF, COSTAS JM.199. Susceptibility of firedamaged pine trees (Pinus pinaster and Pinus nigra) to attacks by Ips sexdentatus and Tomicus piniperda (Coleoptera: Scolytidae). Entomo. Gen 24: 105-114.

https://doi.org/10.1127/entom.gen/24/1999/105

14. PELTONEN M 1999 Windthrows and dead-standing trees as bark beetle breeding material at forest-clearcut edge. Scand J Forest Res 14: 505-511. https://doi.org/10.1080/02827589908540815

15. GIBBS J, INMAN A1991 The pine shoot beetle Tomicus piniperda as a vector of blue stain fungi to windblown pine. Forestry 64: 239-249. https://doi.org/10.1093/forestry/64.3.239

16. SOLHEIM H, LANGSTROM B 1991 Blue-stain fungi associated with Tomicus piniperda in Sweden and preliminary observations on their pathogenicity. Ann Sci Forest 48: 149-156. https://doi.org/10.1051/forest:19910203 
17. BOIS E, Yart A 1999 Bioassays on Leptographium wingfieldii, a bark beetle associated fungus, with phenolic compounds of Scots pine phloem. Europ J Plant Pathol 105: 51-60. https://doi.org/10.1023/A:1008624626399

18. WEGENSTEINER R 2004 Pathogens in bark beetles. Bark and Wood Boring Insects in Living Trees in Europe, a Synthesis, pp. 291-313. In: Lieutier F, Day K, Battisti A, Grégoire JC, Evans H (eds.), Springer, Dordrecht.

19. WEGENSTEINER R., WERMELINGER B, HERMANN M 2015 Biology and ecology of native and invasive species. Natural enemies of bark beetles: predators, parasitoids, pathogens and nematodes, pp. 247-304. Chapter 7. In: Vega FE, Hofstetter RW [eds], Bark beetles: Elsevier, San Diego

20. KOHLMAYR B, WEISER J, WEGENSTEINER R, HANDEL U, ŽIŽKA Z 2003 Infection of Tomicus piniperda (L.)(Coleoptera: Scolytidae) with Canningia tomici sp. n. (Microsporidia: Unikaryonidae). J Pest Science 76: 65-73. https://doi.org/10.1046/j.1439-0280.2003.03013.x

21. UNDEEN A, VAVRA J 1997 In: Lacey, LA (ed) Manual of techniques in insect pathology Research methods for entomopathogenic Protozoa. Chapter IV. Academia Press, San Diego, 117-151. https://doi.org/10.1016/B978-012432555-5/50010-5

22. WEGENSTEINER R, WEISER J 1996 Untersuchungen zum Auftreten von Pathogenen bei Ips typographus (Coleoptera: Scolytidae) aus einem Naturschutzgbiet im Schwarzwald (Baden-Württemberg). Anz Schadlingskd Pfl 69: 162-167. https://doi.org/10.1007/BF01906808

23. FUHRER E 1977 Studien über intraspezifische Inkompatibilität bei Pityogenes chalcographus L. (Col., Scolytidae). Z Angew Entomol 83: 286-297.

https://doi.org/10.1111/j.1439-0418.1977.tb02400.x

24. R CORE TEAM 2014 A Language and Environment for Statistical Computing. [R Foundation for Statistical Computing] (http://www.R-project.org).

25. CEDERVIND J, PETTERSON M, LANGSTROM B 2003 Attack dynamics of the pine shoot beetle, Tomicus piniperda (Col.; Scolytinae) in Scots pine stands defoliated by Bupalus piniaria (Lep.; Geometridae). Agr Forest Entomol 5: 253-261. https://doi.org/10.1046/j.1461-9563.2003.00187.x

26. WITTNER M 1999 Historic perspective on the microsporidia: expanding horizons. In: Wittner M, Weiss LM (eds), The Microsporidia and Microsporidiosis. ASM Press, Washington (DC), 1-6. https://doi.org/10.1128/9781555818227.ch1
27. WEISS LM, BECNEL JJ 2014 Microsporidia: Pathogens of Opportunity. Willey Press, Oxford. https://doi.org/10.1002/9781118395264

28. SOLTER LF, BECNEL JJ, BECNEL DHO 2012 Microsporidian entomopathogens. In: Vega FE, Kaya HK (eds), Insect Pathology. Academic Press 2nd ed,. San Diego, 221-263.

https://doi.org/10.1016/B978-0-12-384984-7.00007-5

29. LANNE B S, SLYTER F, Byers JA, LOVQVIST J, LEUFVEN A, BERGSTROM G, VAN DE PERS JNC, UNELIUS R, BAEKSTROM P, NORTIN T 1987 Differences in attraction to semiochemicals present in sympatric pine shoot beetles, Tomicus minor and T. piniperda. J Chem Ecol 13 (5): 1054-1067

30. HORN A, KERDELHUE C, LIEUTIER F, ROSSI JP 2012 Predicting the distribution of the two bark beetles Tomicus destruens and Tomicus piniperda in Europe and the Mediterranean region. Agr Forest Entomol 14: 358-366.

https://doi.org/10.1111/j.1461-9563.2012.00576.x

31. KERDELHUE C, MAGNOUX M, LIEUTIER F, ROQUES A, ROUSSELET J 2006 Comparative population genetic study of two oligophagous insects associated with the same hosts. Heredity 97: 38-45. https://doi.org/10.1038/sj.hdy.6800836

32. GALLEGO D, CANOVAS F, ESTEVEMA, GALIAN J 2004 Descriptive biogeography of Tomicus (Coleoptera: Scolytidae) species in Spain. J Biogeogr 31: 2011-2024

33. LINDE A, GENTHE C, LACKERJ 1998 The effects of artificial infections with microsporidia on gypsy moth (Lymantria dispar) and nun moth (Lymantria monacha), first results. Proceedings: Population Dynamics, Impacts, and Integrated Management of Forest Defoliating Insects. In McManus ML, Liebhold AM [eds], USDA Forest Service General Technical Report NE-247, 198-205

34. SAITO T, BJORNSON S 2008 Effects of a microsporidium from the convergent lady beetle, Hippodamia convergens Guérin-Méneville (Coleoptera: Coccinellidae), on three non-target coccinellids. J Invertebr Pathol 99: 294-301. https://doi.org/10.1016/j.jip.2008.08.005

35. STEELE T, BJORNSON S 2012 The effects of two microsporidian pathogens on the two-spotted lady beetle, Adalia bipunctata $\mathrm{L}$. (Coleoptera: Coccinellidae). J Invertebr Pathol 109: 223-228. https://doi.org/10.1016/j.jip.2011.11.007

36. MADDOX JV, SOLTER LF 1996 Long-term storage of infective microsporidian spores in liquid nitrogen. J Eukaryot Microbiol 43: 221-225. https://doi.org/10.1111/j.1550-7408.1996.tb01395.x 